\title{
PEMETAAN POTENSI EMISI GRK METANA: SEBAGAI STRATEGI MITIGASI EMISI DAN MENJAGA PRODUKTIVITAS LAHAN PADI SAWAH ORGANIK DI KABUPATEN SRAGEN
}

\author{
Suntoro, Mujiyo, Jauhari Syamsiah \\ Fakultas Pertanian UNS, Jl. Ir. Sutami, No: 36A Ska, 0271637457
}

\begin{abstract}
Abstrak. Pemetaan Potensi Emisi Grk Metana: Sebagai Strategi Mitigasi Emisi Dan Menjaga Produktivitas Lahan Padi Sawah Organik Di Kabupaten Sragen. Tujuan umum penelitian ini adalah memetakan potensi produksi emisi metana pada lahan padi sawah organik di Desa Sukorejo dan Jetis, Kecamatan Sambirejo, Sragen, yang dapat digunakan untuk memitigasi emisi metana dan meningkatkan produktivitas lahan. Secara garis besar pelaksanaan penelitian dibagi menjadi 4 tahap ; (1) karakterisasi tanah dan lahan, pengungkapan secara mendalam karakter obyek lahan pada setiap satuan penggunaan lahan sawah, (2) pengukuran potensi produksi emisi metana, dengan metode inkubasi sampel tanah di laboratorium, sampel gas yang dihasilkan dianalisis menggunakan kromatografi gas yang dilengkapi dengan flame ionization detector (FID) untuk menetapkan flux $\mathrm{CH}_{4}$, (3) analisa data, taraf perbedaan nilai potensi produksi metana diketahui dengan analisis beda nyata Uji $\mathrm{T}$, dan penentuan faktor yang paling berperanan terhadap besarnya potensi emisi metana dengan analisis stepwise regression, dan (4) rekomendasi, pemilihan rekomendasi didasarkan pada praktek budidaya pertanian yang efektif meningkatkan $\mathrm{C}$ organik dan menekan produksi emisi metana tanpa mengurangi produktivitas tanaman. Hasil penelitian menunjukkan bahwa ; (1) potensi produksi metana $\left(\mathrm{CH}_{4}\right)$ berbeda nyata antar satuan penggunaan lahan (SPL) sawah di Desa Sukorejo dan Jetis, (2) iklim, varietas tanaman, dan cara budidaya di daerah penelitian tidak signifikan mempengaruhi besarnya potensi produksi metana, dan (3) faktor yang berpengaruh signifikan terhadap besarnya potensi produksi metana di tanah sawah adalah potensial redoks (Eh). Hubungan Eh dengan besarnya potensi produksi metana berkorelasi negatif, artinya penurunan Eh akan menyebabkan peningkatan potensi produksi metana. Mitigasi emisi GRK metana yang dapat dilakukan berdasarkan hasil penelitian ini, bahwa potensial redoks adalah faktor utama penentu potensi produksi metana di dalam tanah sawah, maka alternatif yang memungkinkan adalah dengan pengelolaan air irigasi, yang dalam periode tertentu tanaman padi tidak diairi atau tidak digenangi, atau apabila kondisi air berlebih dilakukan draenasi. Usaha ini dilakukan dengan tujuan kondisi tanah tidak terlalu reduktif atau potensial redoks tidak akan turun secara drastis, sehingga akan dapat menghambat aktivitas mikrobia methanogen dalam memproduksi metana.
\end{abstract}

Kata kunci: pemetaan, potensi produksi metana, padi sawah organik, mitigasi emisi 


\section{PENDAHULUAN}

Menurut USEPA (2006) sektor pertanian, termasuk lahan sawah, adalah salah satu penyumbang emisi gas rumah kaca (GRK). Sektor pertanian telah menyebabkan emisi GRK sebesar 50\% pada tahun 1990, dan diperkirakan akan mencapai $57 \%$ pada tahun 2020. Sejak tahun 1990, peningkatan suhu udara akibat peningkatan konsentrasi GRK di atmosfer terjadi sangat cepat. Selama 30 tahun terakhir terjadi peningkatan suhu global secara cepat dan konsisten sebesar $0,2^{\circ} \mathrm{C}$ setiap 10 tahun (Anonim, 2007). Fenomena ini disebut sebagai pemanasan global (global warming). Emisi GRK dari lahan sawah diperkirakan akan terus mengalami peningkatan seiring dengan semakin meningkatnya intensitas pengelolaannya.

Sementara itu, sebagian besar lahan sawah di Indonesia berkadar bahan organik sangat rendah (C-organik $<2 \%$ ) (Karama, 2001 ; Syamsiyah dan Mujiyo, 2006). Usaha mengatasi degradasi lahan sawah berkadar bahan organik rendah adalah mengimplementasikannya dengan sistem padi sawah organik, yang salah satu komponennya adalah dengan penggunaan bahan organik (pupuk organik). Namun demikian, ternyata beberapa hasil penelitian menunjukkan bahwa penggunaan pupuk organik (bahan organik) pada tanah sawah meningkatkan produksi gas metana $\left(\mathrm{CH}_{4}\right)$ dan karbondioksida $\left(\mathrm{CO}_{2}\right)($ Nieder and Benbi, 2008). Pada tahun 1990, emisi metana dari tanah sawah diperkirakan mencapai 20-120 juta ton per tahun atau sekitar $12,5 \%$ dari emisi metana global (Sudadi, 2002).

Penilaian bahwa sistem padi sawah organik meningkatkan emisi GRK akan berpengaruh terhadap kenyamanan dan keberlanjutan produksi padi sawah, termasuk di lahan padi sawah organik di Desa Sukorejo dan Jetis, Kecamatan
Sambirejo, Kabupaten Sragen. Oleh karena itu, diperlukan suatu penelitian yang mendalam tentang emisi GRK oleh sistem lahan sawah organik ini pada berbagai perlakuan pengelolaan yang biasa dilakukan oleh petani. Salah satu upaya yang diperlukan adalah dengan melakukan mitigasi emisi GRK secara periodik melalui karakterisasi lahan dan pengukuran besarnya potensi emisi GRK, bagaimana pengelolaan lahan agar dapat meminimalisasi emisi GRK, namun masih dapat meningkatkan produktivitas lahan. Langkah ini memerlukan basis data karakter lahan dan pengelolaannya, serta potensi produksi GRK, untuk memberikan petunjuk dan penyusunan rekomendasi strategi mitigasi emisi GRK $\mathrm{CH}_{4}$ pada lahan padi sawah organik.

Kegiatan yang akan dilakukan sesuai dengan komitmen Pemerintah Indonesia di kancah internasional untuk mengurangi total emisi GRK dari bumi Indonesia. Kegiatan-kegiatan diarahkan untuk mendukung gerakan mitigasi emisi GRK, dan pada tahun 2010 Pemerintah Indonesia mengalokasikan $26 \%$ APBN untuk program pengurangan global warming.

\section{METODE DAN MEKANISME ALIH TEKNOLOGI (DISEMINASI)}

\section{Pendekatan Penelitian}

Penelitian ini merupakan eksploratif research dengan melalui pendekatan survei dan wawancara, serta didukung dengan analisis di laboratorium. Penentuan satuan penggunaan lahan (SPL) didasarkan atas overlay (tumpang susun) dari tema-tema; (1) geologi, (2) jenis tanah, dan (3) topografi (tinggi tempat dan kemiringan lereng). Jumlah SPL didasarkan dari jumlah keseragaman (satuan lahan) yang dihasilkan dari tema-tema tersebut. 


\section{Waktu dan Tempat}

Penelitian akan dilaksanakan pada bulan April sampai dengan Nopember 2011. Tahap survei dan wawancara dilaksanakan di hamparan lahan kelompok tani padi sawah organik dan sekitarnya di Desa Sukorejo dan Jetis, Kecamatan Sambirejo, Kabupaten Sragen. Analisis dan persiapan pemetaan dilaksanakan di Laboratorium Pedologi dan Survei Tanah, Jurusan Ilmu Tanah, Fakultas Pertanian UNS Surakarta. Analisis sifat kimia dan fisika tanah dilakukan di Laboratorium Kimia dan Kesuburan, Jurusan Ilmu Tanah, Fakultas Pertanian UNS Surakarta. Inkubasi sampel tanah dan Analisis Gas Chromatography (GC) dilaksanakan di Laboratorium Gas Rumah Kaca (GRK), Balai Penelitian Lingkungan Pertanian, Jakenan, Pati.

\section{Bahan dan Alat}

Bahan-bahan yang dibutuhkan dalam penelitian ini meliputi; peta (rupa bumi, penggunaan lahan, geologi, jenis tanah), khemikalia untuk analisa sampel tanah, dan khemikalia analisa GC. Kebutuhan alat yang digunakan meliputi ; alat tulis perkantoran, seperangkat komputer dilengkapi scanner, printer dan software ArcView 3.3 GIS (Geographic Information System), alat survey lapangan (GPS, kompas, klinometer, altimeter, ring sample, bor tanah, lup, cangkul, alat tulis), alat penyidikan tanah di lapangan (pisau belati, meteran, MSCC, $\mathrm{pH}$ meter, pipet), alat untuk analisis laboratorium sampel tanah, inkubator tanah dan analisa GC.

\section{Tata Laksana Penelitian}

Secara garis besar pelaksanaan penelitian dibagi menjadi 4 tahap ;

1. Karakterisasi Tanah dan Lahan

Tahap ini merupakan pengungkapan secara mendalam karakter obyek lahan pada setiap SPL. Karakter yang akan dijelaskan dan diduga berpengaruh terhadap besarnya emisi GRK metana adalah sifat tanah (bahan organik, KPK, $\mathrm{pH}$, tekstur, Eh), iklim (curah hujan, suhu), tanaman (varietas), dan cara budidaya (pengolahan tanah, cara tanam, pemupukan, pengairan, panen) (Yagi, et al., 1990; Li, 2007; Changseng, 2007).

2. Pengukuran Potensi Produksi GRK Potensi produksi GRK yang diukur adalah gas metana $\left(\mathrm{CH}_{4}\right)$. Metode pengukuran potensi produksi gas metana dengan metode inkubasi sampel tanah di laboratorium (Susilowati, 2007). Sampel gas yang dihasilkan dianalisis menggunakan kromatografi gas yang dilengkapi dengan flame ionization detector (FID) untuk menetapkan flux $\mathrm{CH}_{4}$ (Susilawati dan Kartikawati, 2008).

3. Analisa Data

Secara garis besar analisa data adalah ; (1) taraf perbedaan nilai potensi produksi metana diketahui dengan analisis beda nyata $\mathrm{Uji} \mathrm{T}$, dan (2) penentuan faktor yang paling berperanan terhadap besarnya potensi emisi metana dengan analisis stepwise regression.

Analisa data secara lengkap disampaikan pada sub bab Teknik Analisa Data

4. Rekomendasi

Rekomendasi disusun berdasarkan tipe pengelolaan lahan sawah yang mampu menjaga atau meningkatkan kadar C dalam tanah, dan menurunkan produksi GRK $\mathrm{CH}_{4}$ atau dalam batas yang masih diperbolehkan. Pemilihan rekomendasi didasarkan pada praktek budidaya pertanian yang efektif meningkatkan $\mathrm{C}$ organik dan menekan produksi $\mathrm{CH}_{4}$ tanpa mengurangi produktivitas tanaman. 


\section{Sumber dan Teknik Pengumpulan Data \\ Sumber data berasal dari pengamatan langsung di lapangan, wawancara (dengan petani, petugas teknis, pejabat dan instansi terkait), data sekunder, dan analisis di laboratorium. \\ Teknik pengumpulan data pada masing-masing SPL adalah:}

\section{Lama melaksanakan sistem padi sawah organik}

Data ini diketahui dengan wawancara kepada petani, kapan petani mulai menggunakan sistem padi organik, kemudian dikonfirmasikan lagi dengan petugas teknis (PPL setempat).

\section{Jenis Tanah}

Pencandraan jenis tanah mengikuti prosedur Soil Taxonomy USDA (Soil Survey Division Staff, 2008). Penggalian tanah untuk pembuatan pedon ukuran 1 m x $1 \mathrm{~m} \times 1 \mathrm{~m}$, kemudian melakukan deskripsi horison dan profil tanah. Apabila masih meragukan untuk mengklasifikasikan langsung di lapangan maka menunggu hasil analisa laboratorium untuk meyakinkan jenis atau nama tanah.

\section{Karakter tanah}

Semua prosedur analisa tanah di laboratorium yang akan dilakukan mengikuti petunjuk teknis dari Balai Penelitian Tanah, Bogor (2005). Karakter tanah yang akan diamati meliputi ; bahan organik, $\mathrm{KPK}, \mathrm{pH}$, tekstur, potensial redoks (Eh), dan suhu tanah (suhu tanah diamati langsung di lahan).

Iklim

hujan dan sengatan unsur iklim (curah pengumpulan data iklim oleh Pertanian dan Tanaman Pangan Kabupaten Sragen minimal 10 tahun terakhir. Data direkapitulasi untuk menentukan curah hujan dan suhu ratarata bulanan dan tahunan.

\section{Pengolahan tanah}

Pengolahan tanah diketahui dengan pengamatan langsung, informasi dari petani, kemudian dikonfirmasikan lagi kepada petugas teknis (PPL setempat). Informasi yang diperlukan adalah cara, alat dan mesin yang digunakan, dan waktu pelaksanaan.

\section{Tanaman}

Data tanaman padi yang perlu diketahui adalah varietas dan deskripsinya. Informasi nama varietas tanaman padi diperoleh dari petani yang menanam kemudian dikonfirmasikan lagi kepada petugas teknis (PPL setempat). Informasi deskripsi varietas padi diperolah dari Dinas Pertanian dan Tanaman Pangan Kabupaten Sragen.

\section{Cara / pola tanam}

Cara / pola tanam diketahui dengan pengamatan langsung, informasi dari petani, kemudian dikonfirmasikan lagi kepada petugas teknis (PPL setempat). Informasi yang diperlukan bagaimana cara tanam pada setiap musim tanam, pola tanam dalam setahun, dan selama sejak melaksanakan pertanian padi organik.

\section{Pemupukan}

Pemupukan diketahui dengan pengamatan langsung, informasi dari petani, kemudian dikonfirmasikan lagi kepada petugas teknis (PPL setempat). Informasi yang diperlukan jenis pupuk (sumber), dosis, waktu, dan cara pemupukan. 


\section{Pengairan}

Pengairan diketahui dengan pengamatan langsung, informasi dari petani, kemudian dikonfirmasikan lagi kepada petugas teknis (PPL setempat). Informasi yang diperlukan sumber air, frekuensi, dan cara pengairan.

\section{Penyiangan}

Penyiangan diketahui dengan pengamatan langsung, informasi dari petani, kemudian dikonfirmasikan lagi kepada petugas teknis (PPL setempat). Informasi yang diperlukan adalah cara, dan waktu atau frekuensi.

\section{Panen}

Panen diketahui dengan pengamatan langsung, informasi dari petani, kemudian dikonfirmasikan lagi kepada petugas teknis (PPL setempat). Informasi yang diperlukan adalah cara, alat dan mesin yang digunakan, penanganan gabah dan limbah jerami, serta hasil gabah kering panen (GKP).

\section{Produksi $\mathrm{CH}_{4}$}

Produksi $\mathrm{CH}_{4}$ diukur dengan inkubasi sampel tanah di laboratorium, kemudian gas yang dihasilkan dibaca dengan GC yang dilengkapi dengan flame ionization detector (FID) untuk menetapkan flux $\mathrm{CH}_{4}$. Pedoman pengukuran produksi gas selengkapnya mengikuti Susilowati (2007). Sampel tanah diambil dari lahan secara komposit pada setiap SPL pada kedalaman olah 20 $\mathrm{cm}$, kemudian dikeringanginkan dan diayak ukuran 80 mesh. Sampel tanah 20 gram dimasukkan ke dalam gelas inkubsi, dan kemudian gelas-gelas yang sudah terisi tersebut dimasukkan ke dalam inkubator. Sampel gas diambil dan diukur pada hari pertama jam ke-0 $\left(\mathrm{C}_{0}\right)$ dan jam ke-24 $\left(\mathrm{C}_{24}\right)$. Pengulangan pengambilan sampel gas dilakukan selama 5 kali dengan interval setiap 4 hari.

Pengukuran masing-masing konsentrasi gas dengan alat GC menggunakan rumus:

\footnotetext{
$\mathrm{Ke}_{1} \mathrm{C}_{\mathrm{x}}$
$\mathrm{A}_{1} \mathrm{~A}_{2}$$\rightarrow \begin{aligned} & \mathrm{C}_{1} \times \mathrm{A}_{2} \\ & \mathrm{C}_{\mathrm{x}}=- \\ & \mathrm{A}_{1}\end{aligned}$

$\mathrm{C}_{1} \quad$ : Konsentrasi gas standar

$\mathrm{A}_{1} \quad$ : Area pembacaan dari integrator untuk standar

$\mathrm{A}_{2}$ : Area pembacaan dari contoh gas yang diukur konsentrasinya

$\mathrm{C}_{\mathrm{x}} \quad$ : Konsentrasi gas yang diukur
}

Setelah mendapatkan konsentrasi $\left(\mathrm{C}_{\mathrm{x}}\right)$ pada jam ke-0 $\left(\mathrm{C}_{0}\right)$ dan ke-24 $\left(\mathrm{C}_{24}\right)$, maka perhitungan produksi gas menggunakan rumus sebagai berikut:

Vhs BM Tst

Produksi $\mathrm{CH}_{4}=\left(\mathrm{C}_{24}-\mathrm{C}_{0}\right) \times \times \times$

$\operatorname{Ke} \quad \mathrm{B} \mathrm{Vm}(\mathrm{Tst}+\mathrm{T})$

Vhs : Volume headspace $(\mathrm{ml})$

B : Berat sampel tanah $(\mathrm{g})$

$\mathrm{BM}$ : Berat molekul $\mathrm{CH}_{4}(16,123 \mathrm{~g})$

$\mathrm{Vm}$ : Volume molekul $\mathrm{CH}_{4}$ pada kondisi standar $\left(273,2{ }^{0} \mathrm{~K}\right)=22,411$

Tst Suhu kondisi standar $\left(273,2^{\circ} \mathrm{K}\right)$

$\mathrm{T}$ Suhu udara saat inkubasi $\left({ }^{0} \mathrm{~K}\right)$ 
Satuan hasil perhitungan adalah $\mathrm{mg}$ $\mathrm{CH}_{4} / \mathrm{g}$ tanah. Perhitungan produksi $\mathrm{CH}_{4}$ untuk luasan 1 ha lahan dengan mengalikan berat tanah seluas 1 ha tersebut. Berat tanah 1 ha diketahui dengan mengalikan data kedalaman efektif tanah, berat volume dan luasnya. Satuan akhir produksi $\mathrm{CH}_{4}$ adalah $\mathrm{kg} / \mathrm{ha}$.

\section{Teknik Analisa Data}

Semua data ditabulasi dan direkapitulasi, secara garis besar data setiap SPL dikelompokkan menjadi 6 (enam) kelompok ; data sifat tanah, iklim, tanaman, cara budidaya, dan potensi produksi GRK, serta hasil GKP. Kemudian dari 6 kelompok data ini dipilahkan lagi menjadi faktor penyebab dan faktor dampak. Faktor penyebab terdiri dari sifat tanah, iklim, tanaman dan cara budidaya, faktor dampak adalah dinamika produksi GRK dan hasil GKP. Penentuan keeratan hubungan antara faktor penyebab dan faktor dampak pada semua SPL menggunakan analisis korelasi (Steel and Torie, 1981), dan penentuan faktor penyebab yang paling berperanan terhadap faktor dampak adalah dengan analisis stepwise regression (Draper and Smith, 1981 ; Montgomery and Peck, 1991). Taraf perbedaan nilai produksi GRK dan hasil GKP pada masing-masing SPL diketahui dengan analisis beda nyata $\mathrm{Uji} T$ (Suryono, 2005). Untuk mengetahui apakah nilai produksi $\mathrm{CH}_{4}$ masih dalam batas yang masih diperbolehkan (ditoleransikan) maka dengan mengharkatkan nilai produksi gas dengan standarisasi emisi GRK.

\section{Teknik Diseminasi Hasil Kegiatan}

Informasi dan rekomendasi yang diperoleh dari hasil kegiatan penelitian akan disosialisasikan melalui forum diskusi langsung (sosialisasi) kepada petani atau melalui jurnal / buku / modul kepada berbagai kalangan pemerintah, praktisi / petani, akademisi, dan pemangku kepentingan lainnya. Ketua kelompok tani, tokoh masyarakat maupun tokoh agama serta petugas penyuluh lapangan sebagai figur panutan (key person) akan sangat berperan untuk membantu dan keberhasilan transfer teknologi dari nara sumber ke petani. Perangkat desa maupun pemda diatasnya serta lembaga pertanian lainnya sebagai fasilitator dalam kegiatan ini, setiap kebijakan yang ditetapkan harus mengakomodasi kepentingan dan keinginan petani untuk menerapkan teknik pengelolaan lahan yang dapat menjaga atau meningkatkan kesuburan dan produktivitas lahan, serta meminimalisir emisi GRK metana. Badan Permusyawaratan Desa (BPD) akan mensupport, advokasi dan kontrol terhadap kepentingan petani melalui kebijakan yang dibuat oleh perangkat desa maupun pemda. Perguruan tinggi yang berfungsi sebagai lembaga penelitian dan pengabdian kepada masyarakat dapat menjadikan kegiatan ini sebagai wadah untuk menjalin kerjasama dengan masyarakat untuk melaksanakan Tri Dharma Perguruan Tinggi. Media ini dapat dimanfaatkan untuk transfer dan aplikasi ilmu yang telah diperoleh perguruan tinggi kepada masyarakat luas. Manfaat yang diperoleh lembaga perguruan tinggi adalah mendapatkan umpan balik dari praktisi (petani) terhadap metode dan hasil penelitian, sehingga dapat dilakukan revisi, penyempurnaan maupun modifikasi. Kegiatan ini juga akan memberikan banyak referensi bagi staf dalam proses belajar mengajar. 


\section{HASIL PENELITIAN DAN PEMBAHASAN}

Wilayah penelitian Desa Sukorejo dan Jetis mempunyai 17 SPL berdasarkan keseragaman geologi, jenis tanah, topografi dan penggunaan lahan sawah. Semula terdapat 19 SPL, tetapi setelah dilakukan survei di lapang, SPL 1 dan 4 sudah berubah penggunaan lahannya menjadi tegalan. Berikut daftar SPL berdasarkan keseragaman geologi, jenis tanah, topografi

Tabel. 1 Daftar SPL berdasarkan keseragaman geologi, jenis tanah, topografi

\begin{tabular}{|c|c|c|}
\hline No. & SPL & $\begin{array}{l}\text { SPL } \\
\text { Geologi - Tanah - Topografi }\end{array}$ \\
\hline 1. & S-1 & $\begin{array}{l}\text { Pliocene Vulcanic - Mediteran Coklat Kemerahan - } \\
\text { Sangat Miring (15-25\%), Bergelombang }-484 \mathrm{mdpl}\end{array}$ \\
\hline 2. & S-2 & $\begin{array}{l}\text { Pliocene Vulcanic - Mediteran Coklat Kemerahan - } \\
\text { Sangat Miring (15-25\%), Berombak - } 454 \text { mdpl }\end{array}$ \\
\hline 3. & S-3 & $\begin{array}{l}\text { Pliocene Vulcanic - Mediteran Coklat Kemerahan - } \\
\text { Sangat Miring (15-25\%), Bergelombang - } 381 \mathrm{mdpl}\end{array}$ \\
\hline 4. & S-4 & $\begin{array}{l}\text { Pliocene Vulcanic - Mediteran Coklat Kemerahan - } \\
\text { Agak Miring (3-8\%), Berombak - } 425 \mathrm{mdpl}\end{array}$ \\
\hline 5. & S-5 & $\begin{array}{l}\text { Pliocene Vulcanic - Mediteran Coklat Kemerahan - } \\
\text { Miring }(8-15 \%) \text {, Berombak }-486 \mathrm{mdpl}\end{array}$ \\
\hline 6. & S-6 & $\begin{array}{l}\text { Pliocene Vulcanic - Mediteran Coklat Kemerahan - } \\
\text { Miring (8-15\%), Berombak - } 456 \mathrm{mdpl}\end{array}$ \\
\hline 7. & S-7 & $\begin{array}{l}\text { Pliocene Vulcanic - Mediteran Coklat Kemerahan - } \\
\text { Sangat Miring (15-25\%), Berombak - } 357 \mathrm{mdpl}\end{array}$ \\
\hline 8. & S-8 & $\begin{array}{l}\text { Pliocene Vulcanic - Mediteran Coklat Kemerahan - } \\
\text { Agak Miring (3-8\%), Berombak - } 332 \mathrm{mdpl}\end{array}$ \\
\hline 9. & S-9 & $\begin{array}{l}\text { Pliocene Vulcanic - Mediteran Coklat Kemerahan - } \\
\text { Agak Curam (25-35\%), Berombak - } 359 \mathrm{mdpl}\end{array}$ \\
\hline 10. & $\mathrm{~J}-2$ & $\begin{array}{l}\text { Old Quartenary Vulcanic Produc - Mediteran Coklat Kemerahan - } \\
\text { Sangat Miring (15-25\%), Bergelombang }-266 \mathrm{mdpl}\end{array}$ \\
\hline 11. & $\mathrm{~J}-3$ & $\begin{array}{l}\text { Old Quartenary Vulcanic Produc - Mediteran Coklat Kemerahan - } \\
\text { Agak Curam (25-35\%), Berbukit - } 291 \mathrm{mdpl}\end{array}$ \\
\hline 12. & J-5 & $\begin{array}{l}\text { Old Quartenary Vulcanic Produc - Mediteran Coklat Kemerahan - } \\
\text { Sangat Miring (15-25\%), Berbukit - } 307 \mathrm{mdpl}\end{array}$ \\
\hline 13. & J-6 & $\begin{array}{l}\text { Old Quartenary Vulcanic Produc - Latosol Coklat - } \\
\text { Sangat Miring (15-25\%), Bergelombang - } 345 \mathrm{mdpl}\end{array}$ \\
\hline 14. & J-7 & $\begin{array}{l}\text { Old Quartenary Vulcanic Produc - Latosol Coklat - } \\
\text { Curam }(35-60 \%) \text {, Bergelombang - } 379 \mathrm{mdpl}\end{array}$ \\
\hline 15. & $\mathrm{~J}-8$ & $\begin{array}{l}\text { Old Quartenary Vulcanic Produc - Latosol Coklat - } \\
\text { Agak Miring (3-8\%), Berombak - } 403 \mathrm{mdpl}\end{array}$ \\
\hline 16. & J-9 & $\begin{array}{l}\text { Old Quartenary Vulcanic Produc - Latosol Coklat - } \\
\text { Agak Miring (3-8\%), Berombak - } 376 \mathrm{mdpl}\end{array}$ \\
\hline 17. & $\mathrm{~J}-10$ & $\begin{array}{l}\text { Old Quartenary Vulcanic Produc - Latosol Coklat - } \\
\text { Sangat Miring (15-25\%), Berombak - } 268 \mathrm{mdpl}\end{array}$ \\
\hline
\end{tabular}




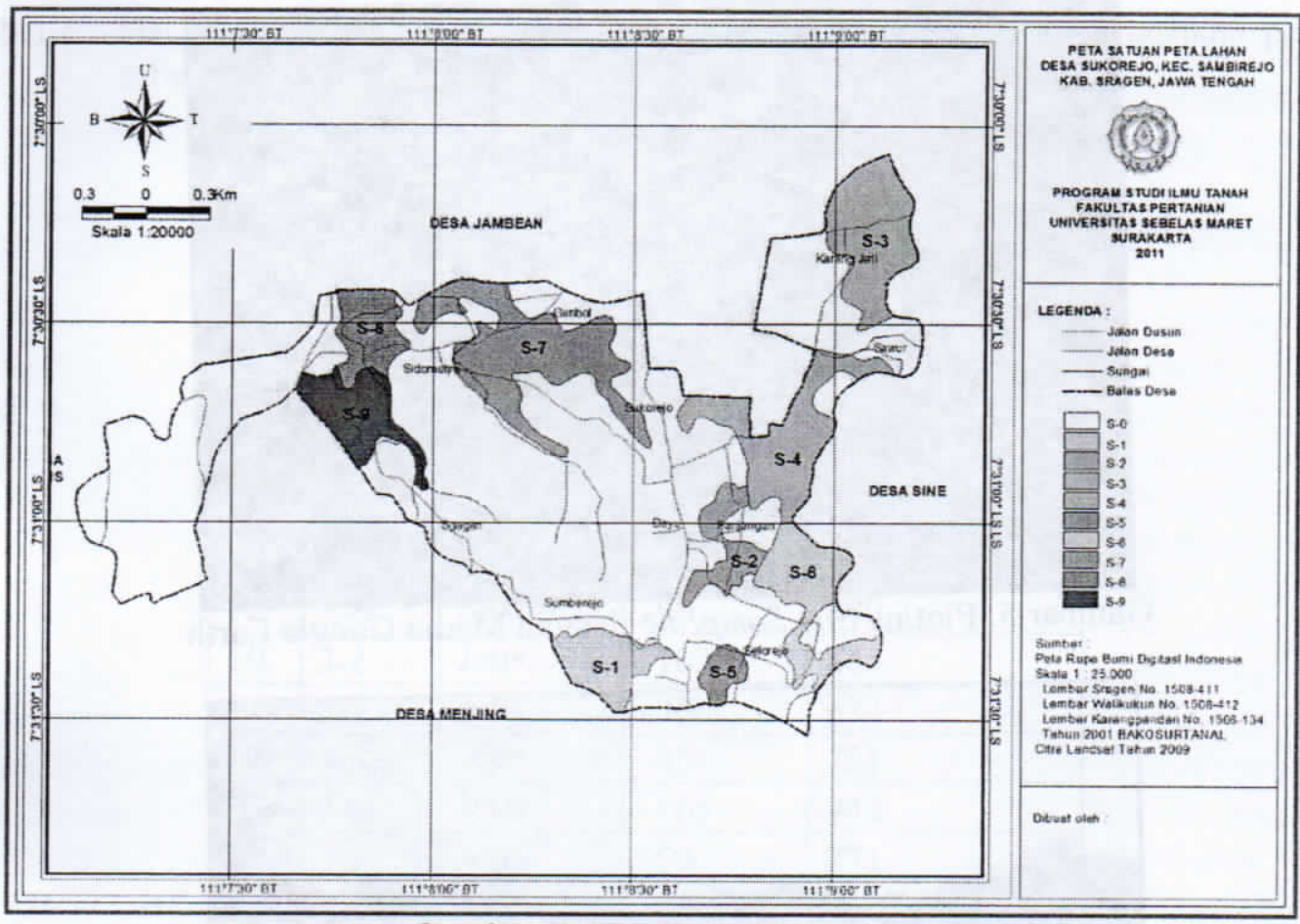

Gambar 3. SPL Desa Sukorejo

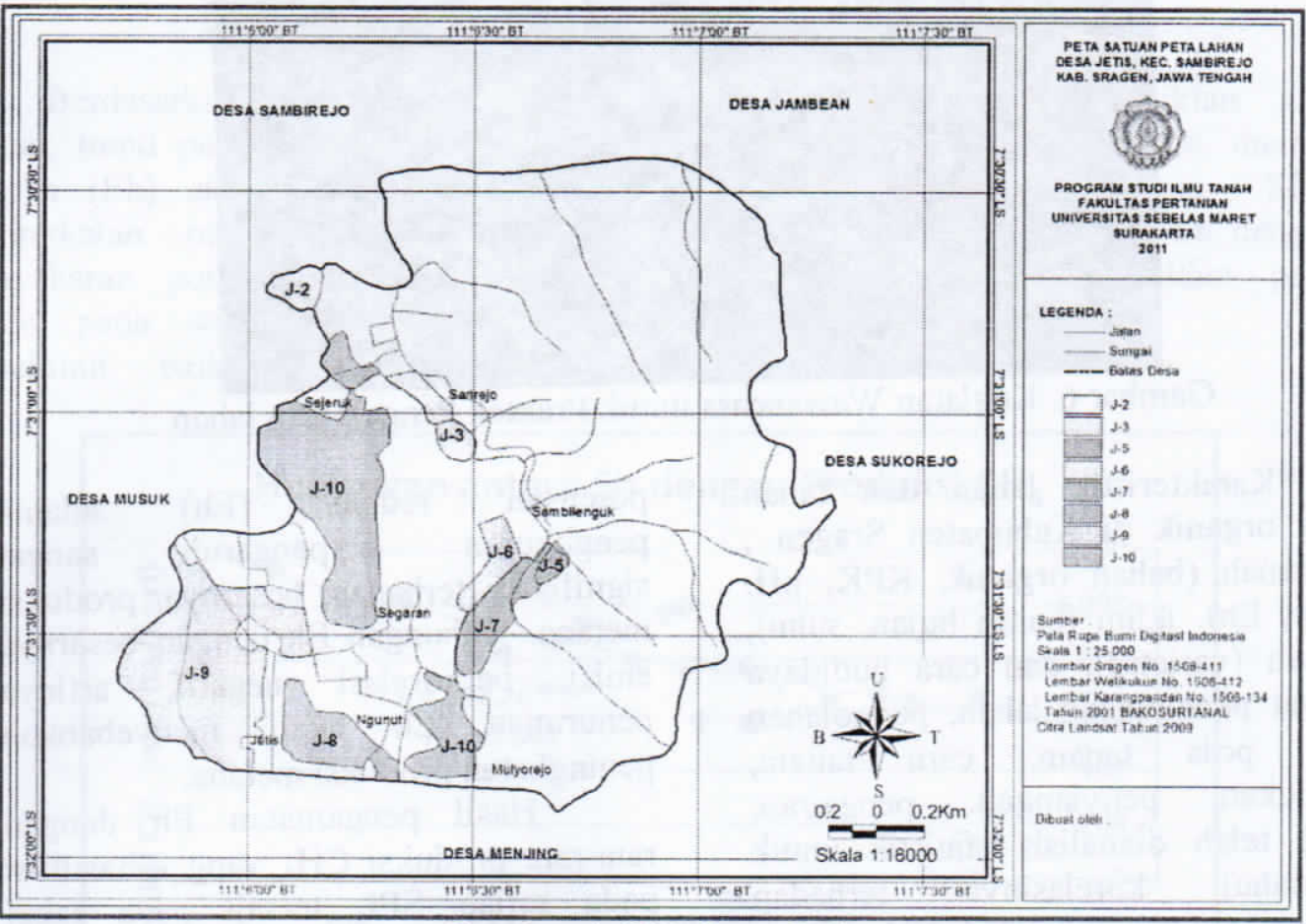

Gambar 4. SPL Desa Jetis 


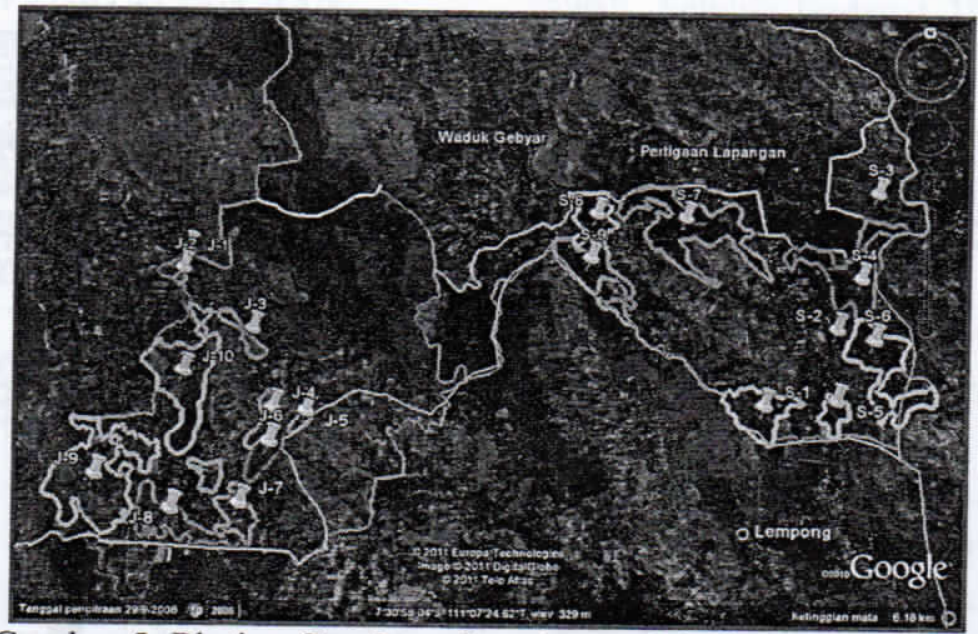

Gambar 5. Ploting Site Sampling dengan Media Google Earth

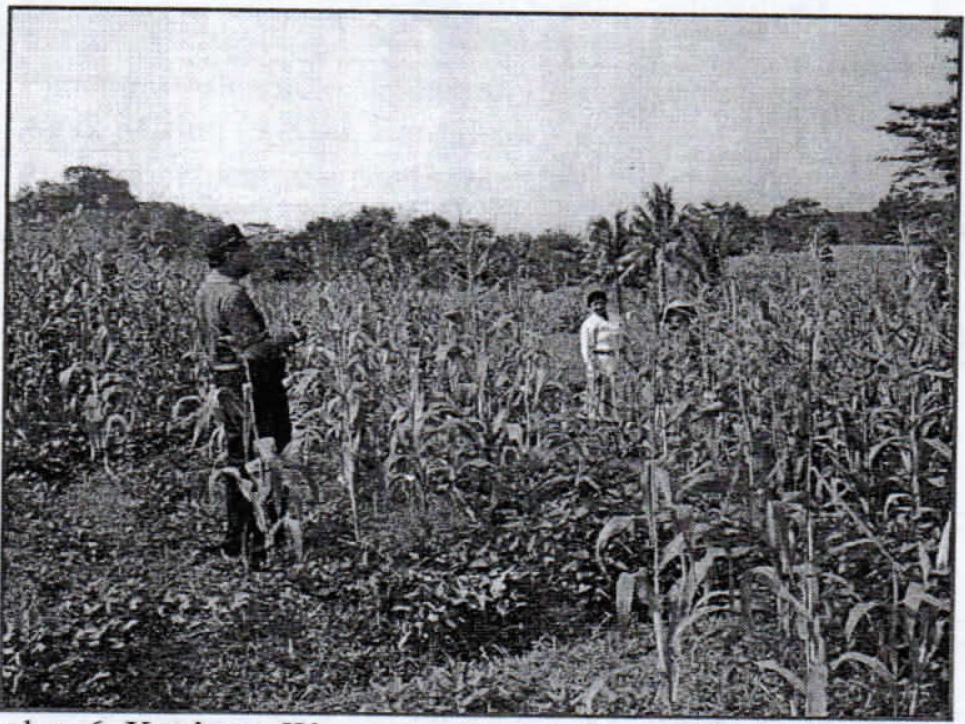

Gambar 6. Kegiatan Wawancara untuk Praktek Pengelolaan lahan

Karakteristik lahan dan tanah sawah organik di Kabupaten Sragen ; sifat tanah (bahan organik, $\mathrm{KPK}, \mathrm{pH}$, tekstur, Eh), iklim (curah hujan, suhu), tanaman (varietas), dan cara budidaya (riwayat penggunaan lahan, pengolahan tanah, pola tanam, cara tanam, pemupukan, penyiangan, pengairan, panen) telah dianalisis statistik untuk mengetahui korelasinya terhadap besarnya potensi produksi $\mathrm{CH}_{4}$. Hasil analisis menunjukkan bahwa iklim, varietas tanaman, dan cara budidaya tidak signifikan mempengaruhi besarnya potensi produksi $\mathrm{CH}_{4}$, sementara itu potensial redoks (Eh) selama pengukuran berpengaruh sangat signifikan terhadap besarnya produksi metana. Hubungan Eh dengan besarnya emisi berkorelasi negatif, artinya penurunan Eh akan menyebabkan peningkatan produksi metana.

Hasil pengamatan Eh dengan rata-rata produksi $\mathrm{CH}_{4}$ yang dihasilkan pada setiap SPL tersaji pada tabel berikut ini: 
Suntoro, Mujiyo, Jauhari Syamsiah: Pemetaan Potensi Emisi GRK...

Tabel 2. Hasil pengamatan Eh dengan rata-rata produksi $\mathrm{CH}_{4}$ yang dihasilkan pada setiap SPL

\begin{tabular}{|l|l|l|l|l|}
\hline No. & SPL & Desa & Eh $(\mathbf{m V})$ & $\begin{array}{l}\text { Produski } \text { CH}_{\mathbf{4}} \\
(\mathbf{m g} / \mathbf{h a} / \mathbf{h a r i})\end{array}$ \\
\hline 1. & S-1 & Sukorejo & -81 & 663 \\
\hline 2. & S-2 & Sukorejo & -99 & 996 \\
\hline 3. & S-3 & Sukorejo & -110 & 823 \\
\hline 4. & S-4 & Sukorejo & -116 & 1.012 \\
\hline 5. & S-5 & Sukorejo & -87 & 675 \\
\hline 6. & S-6 & Sukorejo & -100 & 981 \\
\hline 7. & S-7 & Sukorejo & -107 & 867 \\
\hline 8. & S-8 & Sukorejo & -95 & 567 \\
\hline 9. & S-9 & Sukorejo & -98 & 580 \\
\hline 10. & J-2 & Jetis & -102 & 805 \\
\hline 11. & J-3 & Jetis & -90 & 672 \\
\hline 12. & J-5 & Jetis & -95 & 781 \\
\hline 13. & J-6 & Jetis & -105 & 943 \\
\hline 14. & J-7 & Jetis & -99 & 771 \\
\hline 15. & J-8 & Jetis & -95 & 781 \\
\hline 16. & J-9 & Jetis & -124 & 1.143 \\
\hline 17. & J-10 & Jetis & -85 & 643 \\
\hline
\end{tabular}

Berdasarkan nilai pada tabel diatas, trend penurunan nilai potensial redoks (Eh) akan diikuti oleh trend peningkatan nilai produksi metana. Penyebaran potensial redoks berbeda nyata pada setiap SPL di daerah penelitian, baik di Desa Sukorejo maupun Desa Jetis, demikian juga produksi metananya. Produksi metana berbeda-beda pada semua SPL. Persamaan hubungan antara Eh dengan produksi metana dapat dilihat pada gambar berikut ini

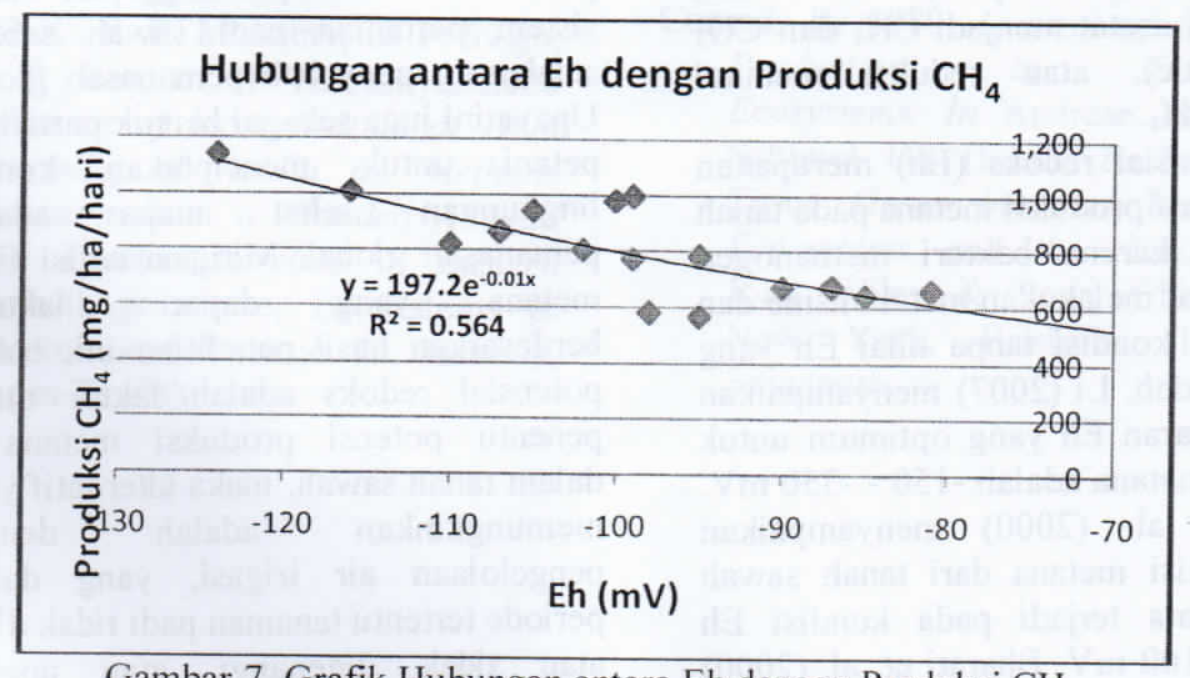

Gambar 7. Grafik Hubungan antara Eh dengan Produksi $\mathrm{CH}_{4}$ 
Berdasarkan gambar diatas, penurunan nilai Eh akan menyebabkan peningkatan produksi metana di dalam tanah, dengan persamaan $y$ (produksi metana $)=197,2 \mathrm{e}^{-0,01 x}$, dan populasi data yang dapat terwakili oleh persamaan tersebut (R-square) $=56,4 \%$. Hal ini menunjukkan bahwa penurunan Eh sangat nyata menentukan peningkatan produksi metana, demikian juga sebaliknya peningkatan Eh sangat nyata menentukan penurunan produksi metana pada tanah sawah. Suasana potensial redoks yang rendah (kondisi reduktif/anaerob) menyebabkan bahan organik didekomposisikan melalui fermentasi methagonik dan menghasilkan $\mathrm{CH}_{4}$ dan $\mathrm{CO}_{2}$. Proses ini berlangsung melalaui 4 (empat) tahap untuk menghancurkan molekul kompleks menjadi senyawa sederhana yaitu ; (1) hidrolisis polimer organik kompleks menjadi monomer (glukosa, asam lemak, asam amino), acidogenesis untuk menghasilkan asam lemak volatil, asam organik, alkohol, $\mathrm{H}_{2}$ dan $\mathrm{CO}_{2}$, (3) acetogenesis dari senyawa yang dihasilkan sebelumnya menghasilkan $\mathrm{CO}_{2}$ dan $\mathrm{H}_{2}$, asetat, dan methanol, dan (4) methanogenesis dengan mereduksi $\mathrm{CO}_{2}$ dan $\mathrm{H}_{2}$ menjadi $\mathrm{CH}_{4}$ (hydrogenotrophic) atau dari fermentasi asetat menjadi $\mathrm{CH}_{4}$ dan $\mathrm{CO}_{2}$ (acetoclastic), atau reduksi metanol menjadi $\mathrm{CH}_{4}$.

Potensial redoks (Eh) merupakan faktor utama produksi metana pada tanah tergenang karena bakteri methanogen hanya dapat melakukan metabolisme dan aktif pada kondisi tanpa nilai Eh yang sangat rendah. Li (2007) menyampaikan bahwa kisaran Eh yang optimum untuk produksi metana adalah $-150--350 \mathrm{mV}$. Hou, et. al. (2000) menyampaikan bahwa emisi metana dari tanah sawah secara nyata terjadi pada kondisi Eh dibawah $-100 \mathrm{mV}$. Bharati et. al. (2000) menyebutkan pada tanah sawah yang tidak dipupuk (kontrol) rata-rata potensial redoksnya $-109,75 \mathrm{mV}$ dan menghasilkan emisi metana sebesar 94,94 kg CH$/$ ha/MT.

\section{KESIMPULAN DAN SARAN}

\section{Kesimpulan}

Potensi produksi metana $\left(\mathrm{CH}_{4}\right)$ berbeda nyata antar satuan penggunaan lahan (SPL) sawah di Desa Sukorejo dan Jetis.

Iklim, varietas tanaman, dan cara budidaya di daerah penelitian tidak signifikan mempengaruhi besarnya potensi produksi metana.

Faktor yang berpengaruh signifikan terhadap besarnya potensi produksi metana di tanah sawah adalah potensial redoks (Eh). Hubungan $\mathrm{Eh}$ dengan besarnya potensi produksi metana berkorelasi negatif, artinya penurunan Eh akan menyebabkan peningkatan potensi produksi metana.

\section{Saran}

Upaya mitigasi emisi GRK metana dengan minimalisasi emisinya akan berdampak kepada kenyamanan usaha tani padi sawah di Indonesia, secara politis akan menepis anggapan bahwa sistem pertanian padi sawah sebagai salah satu penyebab pemanasan global. Upaya ini juga sebagai bentuk partisipasi petani untuk menciptakan kondisi lingkungan sehat tanpa adanya pemanasan global. Mitigasi emisi GRK metana yang dapat dilakukan berdasarkan hasil penelitian ini, bahwa potensial redoks adalah faktor utama penentu potensi produksi metana di dalam tanah sawah, maka alternatif yang memungkinkan adalah dengan pengelolaan air irigasi, yang dalam periode tertentu tanaman padi tidak diairi atau tidak digenangi, atau apabila kondisi air berlebih dilakukan draenasi. 
Usaha ini dilakukan dengan tujuan kondisi tanah tidak terlalu reduktif atau potensial redoks tidak akan turun secara drastis, sehingga akan dapat menghambat aktivitas mikrobia methanogen dalam memproduksi metana.

\section{DAFTAR PUSTAKA}

Agnihotri, S., K. Kulshreshtha, and S. N. Singh. 1998. Mitigation Strategy to Contain Methane Emission from Rice Fields. Environmental Monitoring and Assesment. Kluwer Academic Publisers. Netherlands.

Anonim. 2007. Indonesia dan Perubahan Iklim. Status Terkini dan Kebijakannya. Bank Dunia, DFID dan PEACE.

Ashari. 2003. Tinjauan tentang Alih Fungsi Lahan Sawah ke Non Sawah dan Dampaknya di Pulau Jawa. Forum Penelitian Agro Ekonomi. Volume 21 No. 2, Desember 2003.

Balai Penelitian Tanah. 2005. Analisa Kimia Tanah, Tanaman, Air, dan Pupuk. Badan Penelitian dan Pengembangan Pertanian. Departemen Pertanian.

Bharati, K., S. R. Mohanty, D. P. Singh, V. R. Rao, and T. K. Adhya. 2000 Influence of Incorporation or Dual Cropping of Azolla on Methane Emission from a Flooded Alluvial Soil Planted to Rice in Eastern India. Agriculture, Ecosystems \& Environment Volume 79, Issue 1, Pages $73-83$.
Boeckx, P., and O. V. Cleemput. 1996. Flux Estimates from Soil Methanogenesis and Methanotrophy: Landfills, Rice Paddles, Natural Wetlands and Aerobic Soils. Environmental Monitoring and Assessment 42:189207, 1996. Kluwer Academic Publishers. Printed in the Netherlands.

Bond, D. R. and D. R. Lovley. 2002. Reduction of $\mathrm{Fe}(\mathrm{III})$ Oxide by Methanogens in the Presence and Absence of Extracellular Quinones. Environmental Microbiology. 4(2), 115-124. Blackwell Science Ltd.

Bouwman A. F. 1990. Exchange of Greenhouse Gases between Terrestrial Ecosystems and the Atmosphere. In Bouwman AF (Ed.), Soils and the Greenhouse Effects. John Wiley \& Sons, Chichester, New York, Brisbane, Toronto, Singapore.

Changseng, L. I. 2007. Quantifying Greenhouse Gas Emission from Soils: Scientific Basis and Modelling Approach. Soil Science and Plant Nutrition (2007) 53, 344 352.

Conrad, R. 1989. Control of Methane Production in Terrestrial Ecosystems. In Andreae MO, and Schimel DS (Eds.), Exchange of Trace Gases between Terrestrial Ecosystems and the Atmosphere. John Wiley \& Sons, Chichester, New York, Brisbane, Toronto, Singapore. 
Conrad, R., and H. Schutz. 1988. Methods of Studying Methanogenic Bacteria and Methanogenic Activities in Aquatic Environments. In Austin B. (Ed.), Methods in Aquatic Bacteriology. John Wiley \& Sons, Chichester, New York, Brisbane, Toronto, Singapore.

Conrad, R., H. Schutz, and M. Babbel. 1987. Temperature Limitation of Hydrogen Turn Over and Methanogenesis in Anoxic Paddy Soils. FEM Microbiol. Ecol. 45:281289.

Conrad, R., M. Klose, and P. Claus. 2000. Phospahate Inhibits Acetotrophic Methanogenesis on Rice Roots. Applied and Environmental Microbiology. Feb. 2000. Vol. 66, No. 2. p. 828-831. American Society for Microbiology.

Dinas Pertanian dan Tanaman Pangan Kabupaten Sragen. 2007. Roadmap Komoditas Unggulan "Padi Organik" Kabupaten Sragen. Kerjasama Dinas Pertanian dan Tanaman Pangan Kabupaten Sragen dengan CV. Agrosemar Surakarta.

Draper, N. and H. Smith. 1981. Applied Regression Analysis. Second Edition. John Wiley and Sons, Inc.
Furukawa, Y. and K. Inubushi. 2002. Feasible Supression Technique of Methane Emission from Paddy Soil by Iron Amendment. Nutrient cycling in Agroecosystems.

Graham, S. 2002. Rice Paddy Methane Emissions Depend on Crops' Success. Scientific American News: August 20, 2002.

Holzapfel-Pschorn A., R. Conrad, and W. Seiler. 1986. Effects of Vegetation on The Emission of Methane from Submerged Paddy Soils. Plant Soil.

Hou, A. X., G. X. Chen, Z. P. Wang, O. Van Cleemput, and W. H. Patrick, Jr. Methane and Nitrous Oxide Emissions from a Rice Field in Relation to Soil Redox and Microbiological Processes. Soil Science Society America Journal. Vol. 64, November - December 2000.

Indonesian Organic Farming Certification. 2008. Sertifikat Pangan Organik Diberikan Kepada Asosiasi Petani Organik di Kecamatan Sambirejo, Kabupaten Sragen Jateng. Lembaga Sertifikasi Organik INOFICE.

Johari, J. M. J. dan M. Rachmawati. 2004. Kimia SMA Jilid 1 untuk Kelas X. Penerbit ESIS. Jakarta. 